\title{
Storytelling through the Tik Tok Application Affects Followers' Behaviour Changes
}

\author{
Endang Triwidyati* and Ria Lestari Pangastuti \\ Fakultas Ekonomi Universitas Kadiri, Jawa Timur, Indonesia \\ *Email: endang_triwidyati@unik-kediri.ac.id

\begin{tabular}{|l|}
\hline \\
\hline How to cite (in APA style): \\
Triwidyati, E., Pangastuti, R, L. (2021). Storytelling through the Tik Tok Application Affects Followers' Behaviour \\
Changes. Jurnal Ekonomi dan Bisnis Jagaditha, 8(2), 127-135. doi: https://doi.org/10.22225/jj.8.2.2021.127-135
\end{tabular}

\begin{abstract}
Storytelling is an art that is becoming a trend on social media, nowadays it is starting to be abandoned by switching to story style uploaded via Facebook, Instagram and Tiktok, which have more fans and followers because the story style is clear and solid. Storytelling through the media is a means of influencing audience affection. The storytelling content conveyed includes an event, experience, or inspirational story that is shared by a Tik Tok account owner to his/her followers. This study aims to examine the storytelling through the Tiktok application affects followers' behavior changes. The method used in this study is a qualitative method in which the research data is in the form of information obtained from followers of the Tiktok application related to the context discussed in the video in the Tiktok application. The method of determining the sample of purposive informants is done by determining the research informants deliberately based on predetermined criteria. The result of the storytelling data is the process of building a story that is easily understood and understood successfully to convince the audience that there is value in an action plan that can be carried out. The story is supported by facts and appropriate analysis data. Based on the results obtained from this study, it was found that storytelling was effective in conveying messages of positive change and as it was, there was no fraud or engineering to the followers and came up with very creative ideas.
\end{abstract}

Keywords: followers; lifestyle; social media; storytelling; tiktok application

\section{INTRODUCTION}

After successfully becoming applications that are in demand by many users, Instagram and Tik Tok have become social media with lots of opportunities to carry out story style activities (Su, Baker, Doyle, \& Yan, 2020). In story style social media is used as a practical liaison tool as a means of communication and doing business without having to think about the time and location (Ünlü, Kuş, \& Göksu, 2020). Currently, there are several community forums or organizations that use Tik Tok as a medium for story style activities, Tik Tok is a social project that aims to make social changes to business ventures through storytelling on social media by posting photos and story styles telling stories positive and inspirational from all corners of the archipelago that are able to make the audience feel the condition of that person and are curious to follow it (Bucknell Bossen \& Kottasz, 2020). According to a field study conducted by Zhou, (2019) that in the aspect of motivation, a person is motivated to express himself because of internal and external encouragement through every photo and story style that is posted as well as from the intensive aspect of someone doing selfdisclosure through their Tik Tok posts aimed at All of his followers are intensely about someone's life, especially in the business fields of fashion, culinary, tourist attractions and motivation (Ackermann \& Dewitz, 2020).

Storytelling is a form of communication that is simple, easy to understand, understandable and effective (VázquezHerrero, Negreira-Rey, \& López-García, 2020). Storytelling can carry the audience with the flow and get involved with the contents of the story, and can feel what the characters feel 
in the story because listeners as followers can unconsciously remember experiences that are similar to the story or the story background that has the meaning of personality with themselves (Michele Costabile, 2020). The power of storytelling is what drives a social business project through Tik Tok social media to spread positive and inspirational stories from all corners of the archipelago (Weimann \& Masri, 2020). Tik Tok is an activity to inspire people to break boundaries (Mou, 2020). The Tik Tok account is now followed by more than 50 thousand people from various backgrounds ranging from children, teenagers to the elderly (Haenlein et al., 2020). At a glance similar to Humans of New York by an American photographer, Tik Tok is more than just uploading photos and story styles for Indonesians (Kennedy, 2020). Tik Tok also forms online and offline communities. It is not uncommon to gather together with followers in real life to discuss (Kaye, Chen, \& Zeng, 2021). Storytelling through social media Tik Tok accounts in this study are based on the theory of followership (Hayes, Stott, Lamb, \& Hurst, 2020). Followers is a theory that explains a communication process that starts with a stimulus in the form of a message received by the communicant (Hayes et al., 2020). The stimulus or message conveyed to the communicant may be accepted or may be rejected (Bhandari \& Bimo, 2020). Communication will take place if there is attention from the communicant (Bukauskas, 2020). The next process the communicant understands ( $\mathrm{Su}$ et al., 2020). This communicant ability continues the next process (Hermansdotter \& Cederlind, 2019). After the communicant processes it and receives it, it will produce a response (Bresnick, 2019). The response can include components of attitude, opinion, behavior, cognition, affection and conation (Jung \& Zhou, 2019).

The phenomenon of social media has now become a lifestyle trend such as to cloud photos but it has started to leave now moving to story style such as on Facebook, Instagram, Tik Tok and even many enthusiasts to their followers and with a short story style it is clear that the point of public awareness is still not convinced just become followers. Content homogenization, fake flooding platforms, and lack of platform liquidity (Xu, Yan, \& Zhang, 2019). Currently, social media with the rapid development of the digital information era, every second of society as a human being in the world can provide us with a very extraordinary life experience. After the introduction of the short video application Tik Tok, a commendation for its use was won by excellent disseminated content and high-level creativity in advertising that was very clever which made it fashionable among teenagers, children and even parents. In future developments such applications should be able to further enhance the quality of themselves and create opportunities for sustainable development situations where the platform and its users will live together and grow together in this world (Michele Costabile, 2020).

The stimulus or message conveyed on social media will reach followers, may be it can be accepted or maybe rejected, positive photos and story styles will take place if there is attention from followers and the next process followers will understand (Anderson, 2020). This indirect communication ability will change followers' behavior and social exchange (Lovett, Munawar, Mohammed, \& Prabhu, 2021). Storytelling through the media is a means of influencing audience affection. Storytelling is a force in stimulating the audience to take the desired action. Substantially, storytelling through the media has a great contribution in formulating messages for the audience (Tan \& Weinreich, 2020). In this study, the contents of the storytelling messages conveyed include an event, experience, or inspirational story conveyed by the Tik Tok account to followers. After followers process and receive messages, it is expected that they will produce a response. The response can include components of attitude, opinion, behavior, cognition, affection and conation. In this case, the expected effect is able to provide a change, especially in changes in empathy or sympathy behavior (Yuxin, 2020). In line with what was expressed by Michele Costabile, (2020) which stated that there are three important variables in examining the attitudes formulated in followers' theory, interpretatively storytelling through the media is a stimulus that will be captured by the audience organism. Communication will take place if there is attention from the communicant. The next process the communicant understands. This communicant ability continues the next process. After the communicant processes it and accepts it, there is a willingness to change attitudes (Xu et al., 2019).

There are some related studies with this study have been conducted previously. First, the journal written by Brown et al. (2009). University of Bath, London, and Trento with the title Telling True Stories is an Institute for 
Safe Medication Practices Hallmark, which explains that storytelling can bring listeners to engage with the content of the story, and can feel what the characters feel in the story. This is because the listener can unconsciously remember experiences similar to the story or background stories that have personal meaning to him. People are more able to remember something that happened to them than something that happened to other people. Second, the journal written by Martinus \& Chaniago, (2017) with the title Analysis of Branding Strategy Through Instagram With Storytelling in Creating Brand Image on Proud Project, explains that this field study seeks to determine the effectiveness of social media, especially Instagram rather than media. Other social aspects in terms of forming a brand image are found that the use of storytelling techniques encourage the process of forming a brand image on Instagram social media. How to use storytelling techniques as a branding strategy through Instagram social media is a very important element in a company. Storytelling plays a role in communicating the company's brand and values. In-company storytelling provides a unique and emotional product experience. Apart from that, storytelling is also a branding tool which is an element that uniquely introduces a company to competitors. Third, the journal written by Grissinger, (2014) entitled Telling True Stories Is an Institute for Safe Medication Practices Hallmark, in his study said that there are several components of The Power of Storytelling including: 1) the story is able to attract attention, 2) stories promote critical thinking, 3) stories impress, 4) stories create empathy, 5) stories inspire change. This component is used by researchers as an indicator to see the influence of storytelling through social media on changes in empathy behavior. Fourth, the journal written by Seyf \& Uzun, (2017) with the title Instagram Stories From The Perspective of Narrative Transportation Theory, in this study, Instagram is considered a storytelling tool. It is apparent that the page was used as a storytelling tool when the official pages of the Canadian Cancer Society were analyzed. Symbols, rituals, heroes and values are analyzed by means of stories presented by means of visual posts, and they process influence on observed attitudes and behaviors by evaluating their effect on the audience. As a consequence of this, it is seen that Instagram's narrative adds value, not only to individuals, but also to companies. In the context of developing corporate communication it is seen that they contribute to many public relations measures such as institutionalization, branding and company reputation. The fifth is journals written by Ayub et al. (2017) are entitled Self Disclosure Chef Agus Sasirangan on Instagram Social Media. This field study states that in the motivational aspect, a person is motivated to express himself because of internal and external encouragement through every photo posted and from the intensive aspect someone expresses himself through his Instagram posts aimed at all of his followers intensely about one's life, especially in fashion, culinary and motivation. Grounded by the explanation and the previous study described above, thus this study aims to examine the storytelling through the Tiktok affects followers' behavior changes.

\section{CONCEPTUAL FRAMEWORK}

\section{Mass media}

According to Mou, (2020), mass communication is a message communicated through the mass media to a large number of people. Meanwhile, a more detailed definition of mass communication was put forward by communication expert Vázquez-Herrero et al. (2020) mass communication is production and distribution based on technology and institutions from the continuous flow of messages and the most widely owned by people in industrial society. Meanwhile, according to Michele Costabile, (2020), it is stated that mass communication is a process in which messages that are mass-produced or not the least are spread to a broad, anonymous, and heterogeneous mass of message recipients.

\section{New Media}

The presence of new types of media has expanded and changed the entire spectrum of socio-technological possibilities for public communication. Social media such as Facebook, Twitter, Instagram and Path are new types of media included in the online media category. These new types of media allow people to speak, participate, share and create networks online (Lovett et al., 2021). Ayub et al., (2017) also describes the main features that mark the difference between new media and old (conventional) media based on user perspectives, namely: 1. Interactivity Indicated by the ratio of responses or initiatives from users to offers from sources or senders. 2. Social Presence Experienced by users, a sense of personal contact with other people can be created through the use of a medium. Media Richness: (new) media can bridge differences 
in reference frames, reduce ambiguity, provide cues, be more sensitive and more personal. 3 . Autonomy A user feels in control of the content and uses it and is independent of the source. 4. Playfulness Used for entertainment and enjoyment. 5. Privacy The degree to which media content and use is personal and unique.

\section{Communication}

As a social being, communication is fundamental to humans. The term communication itself comes from Latin, which is communicates which means sharing or belonging together. Sapienza, Iyer, \& Veenstra, (2015) mentions three basic functions that cause the need for humans to communicate, namely because of the human desire to control their environment, human efforts to adapt to their environment, and efforts to transform the legacy of socialization. Sapienza et al., (2015) also gave his paradigm to understand communication more easily, namely by dividing communication into five elements in the question "who says what in which channel to whom with what effect?"

\section{Storytelling through Social Media}

With the ease of using new media nowadays, it gives some communities their own interest to carry out a campaign. As has been done by the Proud Project community, where the community takes advantage of the power of storytelling through the media to make a social change. Storytelling through the media in this study is based on the theory of storytelling and followers. Martinus \& Chaniago, (2017) explains that storytelling and followers' theory is a theory that describes a communication process that starts from a stimulus in the form of a message received by the communicant. Storytelling is a communication medium in the form of delivering messages through stories or stories conveyed by storytellers or storytellers with clear, memorable and interesting intonations so that they can be well received, and can be useful in the future (Brown et al., 2009).

The Tik Tok application can become popular culture in Indonesia, for several reasons, namely (Zhao et al., 2019).

Short Videos that are close to common realities and situations

Videos and short songs made by creators (the name for content creators on Tiktok) have a close relationship with the realities of society, and are wrapped in entertainment, science and fashion as the main content so that they easily attract the attention of the audience.

\section{Simple Short Video Service}

On Tik Tok creators are free to create video content with a short duration (15 seconds to 1 minute), here the creator is given the convenience of creating content, starting from selecting songs that already have a "search" service and this song selection service also provides convenience with classify existing songs, from genres to classifications that are currently trending, if the creator does not know the title of the song he will use, the creator can directly select the song title on the video creator who uses it, so that the complicated content production process in the past has been minimized.

\section{Friendly Application Interface}

Of all the services (features) that pamper creators and audiences, their use will not be maximized without an easy and user friendly interface, Tik Tok provides such convenience so that Tik Tok users can choose their own music interface, add special effects such as beauty and slow motion, and then make a short video of their favorite music.

\section{Advanced Production Level}

Tik Tok can easily develop into popularity because they implement the function of pushing content that is produced accurately according to user preferences and needs, this can be realized because the technology used is quite capable so that the videos that are served on the main page are related to users.

\section{Freedom for Users}

The Tik Tok application provides freedom for its users in accordance with communication theory, which is helping people to express themselves and record a good life is the meaning of the existence of the video (Brüggemann, Engesser, Büchel, Humprecht, \& Castro, 2014). After entering the Tik Tok homepage, it is the content that is recommended by Tik Tok for the audience. Mobile users can switch freely or slide. Double click on the screen for content you like to like the collection. The message function on the right side of the screen also allows the audience to participate in interactions and comments in real time. The message function is a forwarding function, where viewers can share this video to Whatsapp, Facebook, Instagram, Insta stories, Line, Telegram and also email. The operation is simple and convenient, and can meet various user requirements in no time.

The main content that discusses current 
trends.

Tik Tok users, who are mostly millennials, really follow the current trends, from fitness trends, emotional expectations, beautiful scenery, beauty and physical movements that represent current fashion trends.

\section{Celebrity Effect}

With the increasing number of celebrities in Indonesia using the Tik Tok application, people are following it. If in 2017 very few homeland celebrities used Tik Tok, now many celebrities have created their Tik Tok accounts, and reposted them to their other social media accounts.

\section{Attractive marketing}

Tik Tok markets their app attractively, by reducing expression costs and increasing content that is fun and can contribute to the rapid spread of video (Herrero, Humprecht, Engesser, Brüggemann, \& Büchel, 2017).

\section{Storytelling \& Followership}

According to Smith \& Rudolph, (1992) suggests that storytelling is an art of narrative skills from stories in the form of poetry or prose in videos, which are shown or led by one or more people in front of an audience directly where the story can be narrated by telling or sung without Music, pictures, videos or with other accompaniments may be learned orally either through printed materials or through mechanical recording sources. The storytelling method or storytelling is the right method to meet these needs because in stories there are values that can be developed (Woodside, Sood, \& Miller, 2008). Followership is the willingness between the leader and the followers (video maker and following the video) to work together to achieve common goals, show abilities in individuals or groups and build a mutually supportive atmosphere between the leader and his followers (Jorgensen, Strand, \& Boje, 2013). There is no leadership without followers and there is no participation without leadership where both of them are interconnected, communicate and interact with each other (Woodside, 2010).

\section{Behavior of Empathy}

According to Jung \& Zhou, (2019), it explains that empathy is a person's ability to understand and understand other people's feelings and emotions and the ability to imagine oneself experiencing the same feelings as that person. Zhou, (2019) explain that empathy is the ability to understand something from the unique point of view of others. There are several components in empathy, according to Allport, (1962) these components include:

\section{Cognitive component}

The cognitive component is a component that creates an understanding of how other people feel, a component whose job is to understand how other people think so that it creates feelings of empathy.

\section{Affective component}

The affective component sees empathy as an emotional observation that responds to other affective ones that arise. These levels of affective empathy vary. There are some individuals who have good accuracy, this means that the individual can feel very well how other people feel. And some of them have poor accuracy, the meaning is that the individual is not able to feel how the other person feels.

\section{Affective and cognition components}

This component is a composite component of the affective component and the cognitive component. Some experts agree that these two components cannot be separated because they are related. When individuals understand how other people feel, there are emotional feelings that arise from the individual which causes the individual to take an act of empathy for others.

The communicative component

This component arises because of the relationship between the affective component and the cognitive component. This component is very important because with communication, individuals can explore their thoughts and feelings for others, giving rise to a sense of empathy.

\section{METHOD}

This study applied a qualitative research method. Qualitative research tries to capture as much information as possible from various sources, especially from the followers of the Tik Tok application that are related to the context (Creswell, 2013). In this study, researchers used a purposive sample informant determination method by deliberately determining the research informants based on predetermined criteria. The criteria taken in this study are aimed at Indonesians who have used the Tik Tok application and as followers (Gioia, Corley, \& Hamilton, 2013). This study uses semistructured interviews, which are commonly called in-depth interviews with the aim of obtaining primary data from informants 
who are included in the predetermined criteria for completeness of information in this research (Hesse-Biber, 2010). Researchers also used the observation data collection method of users of the tik tok application as followers of observations at the location of the city of Kediri and the study used observation guidelines so that the researcher had signs in making observations around the location of the city of Kediri. Analysis of the data in this study using methods that are inductive and in the form of a narrative. This independent analysis method was carried out because this study originated from field observations which saw the storytelling phenomenon of followerships in the Tik Tok application in Kediri (Pandit, 1996).

\section{RESULT AND DISCUSSION}

The development of social media is currently progressing so rapidly and has many fans. One of the social media that has a lot of fans is the Tiktok application. The tiktok application is one application that has been widely downloaded and used among teenagers. Tiktok is not only used as a means of entertainment, but also as a means of education such as storytelling. Storytelling is mostly done on the tiktok application and storytelling also affects followers. Therefore, this study examines how storytelling through the tiktok application affects followers' behavior changes. Based on the analysis, the results obtained can be explained below.

\section{Storytelling to Followers (Customer, Audience)}

The result of the storytelling data is the process of building a story that is easily understood and understood successfully to convince the audience that there is value in an action plan that can be carried out. The story is supported by facts and appropriate analysis data, so that we can provide the audience with appropriate recommendations and action plans. The ability that is expected from data storytelling is the creative ability that each individual has, the abilities that any data scientist or data analyst is expected to have. Without good storytelling data, many of the results of our analysis and modeling will be wasted because the business team does not carry out the results of our recommendations. The essence of data storytelling is to convince the audience of the results of the data science that has been done.

The storytelling technique is one of the business techniques in online marketing, this technique is a technique of telling stories about the business products we sell. Storytelling techniques can also bring in a lot of followers or as customers and can accurately increase revenue turnover. We can also provoke storytelling ideas with words that we specify such as inspirational words, positive words and healthy words. So we must first determine our words that make the storytelling material and then after a long time the idea will build up from that word. And just adjust the words that fit the video displayed in the Tik Tok application so that followers or audience as customers can be interested and follow our video storytelling. Storytelling is also useful not only as promotional writing but also useful for having artistic and selling value simultaneously.

\section{Benefits of Storytelling}

Storytelling has several benefits such as creating a happy atmosphere, giving pleasure, joy, and enjoyment to develop the listener's imagination. Beside that storytelling provides new experiences and develop listener insights and can also provide a good understanding of themselves and other people around them, can provide new experiences including life problems that exist in the environment and listeners learn to speak in a pleasant style and increase vocabulary and language, train the listener's comprehension and concentration power. In addition, storytelling trains the thinking power and fantasies of the listener and also instills the values of wisdom and character. The other benefits of storytelling are fostering creativity when followers listen to a story enthusiastically, they will be stimulated to imagine the storyline describing a character and instill an idea or idea. Increasing intelligence thanks to a high curiosity or curiosity in followers, it will be able to process the storyline in their thinking. After the video story is finished, the followers understand the message contained in the story (moral message). Hail is useful for teaching him to do well and to practice critical and positive thinking. Avoiding senility when storytelling will make followers try to always remember all the components in the story. Starting from the characters to the story line. Practice remembering by retelling the entire story in his own words and memorizing it. The stories told can help the body produce the hormone dopamine. Hormones themselves are directly related to pleasure. This is similar to the hormone oxytocin, which is associated with feelings of joy and serotonin, which is associated with calm. Stories are also very 
effective because they can make the brain process the imagination like it processes reality. The stories told can also spur brain cells to connect with each other. There is a common brain pattern that both storytellers and listeners will have. Stories also make the brain stimulated not only in thinking but also feeling.

Storytelling is given to story listeners and responds to stories before being given intervention. The response can be in the form of concluding the moral message of the story, telling something similar to the story being discussed and the subject's personal experience related to the moral message of the story being discussed. Through the storytelling intervention, researchers convey messages of change which are packaged in stories experienced in daily life so that they are easily understood by the subject.

The use of storytelling has a significant effect on conveying messages of change to the measurement after the intervention to followers. This is in accordance with the opinion of Zhao et al., (2019) which states that stories help someone to understand something complex because stories are easy to remember, are not hierarchical and are general in nature. This story is also able to bring people to the same understanding, empathize with other people's experiences and ultimately be able to change one's perception.

The results above are in line with the research conducted by Holt et al. (2007) which states that readiness for change is created in the delivery of messages of change from leaders to followers where the messages of change will answer uncertainties in organizational members. This is reinforced by Elving, (2005) which states that effective communication can affect readiness through the role of information about change, creating community spirit and reducing the level of uncertainty and feelings of insecurity at work. Also states that face-to-face communication with recipients of change messages is more effectively used to convey change messages. Communication and interaction between the implementers and recipients of change are needed to make change happen. Together they discuss the practical consequences and what measures are needed to support change. Collaboration on change will lead to a positive response to these changes and people will be more enthusiastic and committed to change (Chawla \& Kevin Kelloway, 2004).

\section{CONCLUSION}

Based on the results and discussion explained above, thus it can be concluded that storytelling was effective in conveying messages of positive change and as it was, there was no fraud or engineering to followers and generated very creative ideas or ideas, so the readiness for significant change also increased over time. The use of storytelling is effective in increasing readiness for digital change. After understanding the meaning of storytelling, you will know that storytelling cannot be separated from the world of digital marketing. By making storytelling that is different from the others, it will certainly attract the attention of its followers.

\section{REFERENCES}

Ackermann, J., \& Dewitz, L. (2020). Kreative Bearbeitung politischer Information auf TikTok. MedienPädagogik: Zeitschrift Für Theorie Und Praxis Der Medienbildung, 38 (38), 69-93. https://doi.org/10.21240/ mpaed/38/2020.11.16.X

Allport, F. H. (1962). A structuronomic conception of behavior: Individual and collective: I. Structural theory and the master problem of social psychology. The Journal of Abnormal and Social Psychology, 64(1), 3-30. https:// doi.org/10.1037/h0043563

Anderson, K. E. (2020). Getting acquainted with social networks and apps: it is time to talk about TikTok. Library Hi Tech News, 37(4), 7-12. https://doi.org/10.1108/LHTN-012020-0001

Ayub, K., Novaria, M., \& Muhammad, A. (2017). Self Disclosure Chef Agus Sasirangan Di Media Sosial Instagram. MetaCommunication; Journal of Communication Studies, 1(2), 1-58. https:// doi.org/http://dx.doi.org/10.20527/ mc.v1i2.4123

Bhandari, A., \& Bimo, S. (2020). Tiktok and the "Algorithmized Self": a New Model of Online Interaction. AoIR Selected Papers of Internet Research, 27(10), 1-3. https:// doi.org/10.5210/spir.v2020i0.11172

Bresnick, E. (2019). Intensified Play: Cinematic study of TikTok mobile app. University of Southern California, 4(4), 1-12. Retrieved from https://www.academia.edu/40213511/ Intensified_Play_Cinematic_study_of_TikT ok_mobile_app? from $=$ cover - page

Brown, A. D., Gabriel, Y., \& Gherardi, S. (2009). Storytelling and Change: An Unfolding Story. Organization, 16(3), 323-333. https:// doi.org/10.1177/1350508409102298

Brüggemann, M., Engesser, S., Büchel, F., Humprecht, E., \& Castro, L. (2014). Hallin and Mancini Revisited: Four Empirical Types of Western Media Systems. Journal 
of Communication, 64(6), 1037-1065. https://doi.org/10.1111/jcom.12127

Bucknell Bossen, C., \& Kottasz, R. (2020). Uses and gratifications sought by pre-adolescent and adolescent TikTok consumers. Young Consumers, 21(4), 463-478. https:// doi.org/10.1108/YC-07-2020-1186

Bukauskas, D. (2020). MARKETINGO KOMUNIKACIJOS SOCIALINIAME TINKLE, TIKTOK“ POVEIKIO VARTOTOJU ELGSENAI VERTINIMAS. PREKÉS Z̈ENKLO,,PILDYK“ ATVEJIS. Retrieved from https://www.vdu.lt/cris/ bitstream/20.500.12259/106619/1/

domantas bukauskas bd.pdf

Chawla, A., \& Kevin Kelloway, E. (2004). Predicting openness and commitment to change. Leadership \& Organization Development Journal, 25(6), 485-498. https://doi.org/10.1108/01437730410556734

Creswell, J. W. (2013). Qualitative Inquiry \& Research Design; Choosing Among Five Approaches. Los Angeles: SAGE Publications, Inc.

Elving, W. J. L. (2005). The role of communication in organisational change. Corporate Communications: An International Journal, 10(2), 129-138. https:// doi.org/10.1108/13563280510596943

Gioia, D. A., Corley, K. G., \& Hamilton, A. L. (2013). Seeking Qualitative Rigor in Inductive Research. Organizational Research Methods, 16(1), 15-31. https:// doi.org/10.1177/1094428112452151

Grissinger, M. (2014). Telling true stories is an ISMP hallmark: Here's why you should tell stories, Too. Medication Errors, 39(10), 658 -659. Retrieved from https://www.ismp.org/ resources/telling-true-stories-ismp-hallmarkheres-why-you-should-tell-stories-too

Haenlein, M., Anadol, E., Farnsworth, T., Hugo, H., Hunichen, J., \& Welte, D. (2020). Navigating the New Era of Influencer Marketing: How to be Successful on Instagram, TikTok, \&amp; Co. California Management Review, 63(1), 5-25. https:// doi.org/10.1177/0008125620958166

Hayes, C., Stott, K., Lamb, K. J., \& Hurst, G. A. (2020). "Making Every Second Count": Utilizing TikTok and Systems Thinking to Facilitate Scientific Public Engagement and Contextualization of Chemistry at Home. Journal of Chemical Education, 97(10), 3858-3866. https://doi.org/10.1021/ acs.jchemed.0c00511

Hermansdotter, M., \& Cederlind, J. (2019). Tick tack , Tik Tok . Hög tid att lära känna den moderna tidens opinionsbildare. Stockholm Business School, 15, 1-53. Retrieved from https://www.precis.se/wp-content/ uploads/2020/05/Tick-tack-Tik-Tok.-Hogtid.pdf

Herrero, L. C., Humprecht, E., Engesser, S.,
Brüggemann, M., \& Büchel, F. (2017). Rethinking Hallin and Mancini beyond the west: An analysis of media systems in Central and Eastern Europe. International Journal of Communication, 11(3), 47974823. https://doi.org/10.5167/uzh-144867

Hesse-Biber, S. (2010). Qualitative Approaches to Mixed Methods Practice. Qualitative Inquiry, 16(6), 455-468. https:// doi.org/10.1177/1077800410364611

Holt, D. T., Armenakis, A. A., Feild, H. S., \& Harris, S. G. (2007). Readiness for Organizational Change. The Journal of Applied Behavioral Science, 43(2), 232255. doi.org/10.1177/0021886306295295

Jorgensen, K., Strand, A., \& Boje, D. (2013). Towards a Postcolonial-storytelling Theory of Management and Organisation. Philosophy of Management, 12(1), 43-66. https://doi.org/10.5840/pom20131214

Jung, H., \& Zhou, Q. (2019). Learning and Sharing Creative Skills with Short Videos: A Case Study of User Behavior in TikTok and Bilibili. International Association of Societies of Design Research, 2(5), 1-16. Retrieved from https:// www.researchgate.net/ publication/335335984_Learning_and_Shari ng_Creative_Skills_with_Short_Videos_A Case_Study_of_User_Behavior_in_TikTok_ and $\bar{B}$ ilibili

Kaye, D. B. V., Chen, X., \& Zeng, J. (2021). The co-evolution of two Chinese mobile short video apps: Parallel platformization of Douyin and TikTok. Mobile Media \& Communication, 9(2), 229-253. https:// doi.org/10.1177/2050157920952120

Kennedy, M. (2020). 'If the rise of the TikTok dance and e-girl aesthetic has taught us anything, it's that teenage girls rule the internet right now': TikTok celebrity, girls and the Coronavirus crisis. European Journal of Cultural Studies, 23(6), 1069-1076. https://doi.org/10.1177/1367549420945341

Lovett, J. T., Munawar, K., Mohammed, S., \& Prabhu, V. (2021). Radiology Content on TikTok: Current Use of a Novel VideoBased Social Media Platform and Opportunities for Radiology. Current Problems in Diagnostic Radiology, 50(2), 126-131. https://doi.org/10.1067/ j.cpradiol.2020.10.004

Martinus, H., \& Chaniago, F. (2017). Analysis of Branding Strategy through Instagram with Storytelling in Creating Brand Image on Proud Project. Humaniora, 8(3), 201. https:// doi.org/10.21512/humaniora.v8i3.3678

Michele Costabile, D. Q. (2020). L'evoluzione del social media marketing: arriva Tik Tok (Luiss Guido Carli). Retrieved from https:// tesi.luiss.it/id/eprint/27536

Mou, J. B. (2020). Study on Social Media 
Marketing Campaign Strategy-TikTok and Instagram. MIT Sloan School of Management, 3(8), 1-41. Retrieved from https://dspace.mit.edu/ handle/1721.1/127010

Ochs, E., Taylor, C., Rudolph, D., \& Smith, R. (1992). Storytelling as a theory $\square$ building activity. Discourse Processes, 15(1), 37-72. https://doi.org/10.1080/01638539209544801

Pandit, N. (1996). The Creation of Theory: A Recent Application of the Grounded Theory Method. The Qualitative Report, 2(24), 115. $3715 / 1996.2054$ https://doi.org/10.46743/2160-

Sapienza, Z. S., Iyer, N., \& Veenstra, A. S. (2015). Reading Lasswell's Model of Communication Backward: Three Scholarly Misconceptions. Mass Communication and Society, 18(5), 599-622. https:// doi.org/10.1080/15205436.2015.1063666

Seyf, M., \& Uzun, A. (2017). Instagram Stories From the Perspective of Narrative Transportation Theory. The Turkish Online Journal of Design, Art and Communication, 7(1), 47-60. https:// doi.org/10.7456/10701100/005

Su, Y., Baker, B. J., Doyle, J. P., \& Yan, M. (2020). Fan Engagement in 15 Seconds: Athletes' Relationship Marketing During a Pandemic via TikTok. International Journal of Sport Communication, 13(3), 436-446. https://doi.org/10.1123/ijsc.2020-0238

Tan, A. S. L., \& Weinreich, E. (2020). \#PuffBar: how do top videos on TikTok portray Puff Bars? Tobacco Control, 11(8), tobaccocontrol-2020-055970. https:// doi.org/10.1136/tobaccocontrol-2020055970

Ünlü, D. G., Kuş, O., \& Göksu, O. (2020). "Videolarda Gerçek Hayattaki Gibi Değilim, Rol Yapmaktayım": TikTok Kullanıcılarının Benlik Performansları Üzerine Bir İnceleme. Intermedia International E-Journal, 7(12), 115-128. https://doi.org/10.21645/intermedia.2020.70

Vázquez-Herrero, J., Negreira-Rey, M.-C., \& López-García, X. (2020). Let's dance the news! How the news media are adapting to the logic of TikTok. Journalism, 1(10), 146488492096909 doi.org/10.1177/1464884920969092

Weimann, G., \& Masri, N. (2020). Research Note: Spreading Hate on TikTok. Studies in Conflict \& Terrorism, O(0), 1-14. https:// doi.org/10.1080/1057610X.2020.1780027

Woodside, A. G. (2010). Brand-consumer storytelling theory and research: Introduction to a Psychology \& Marketing special issue. Psychology \& Marketing, 27 (6), 531-540. https://doi.org/10.1002/ mar. 20342

Woodside, A. G., Sood, S., \& Miller, K. E. (2008). When consumers and brands talk:
Storytelling theory and research in psychology and marketing. Psychology and Marketing, 25(2), 97-145. https:// doi.org/10.1002/mar.20203

Xu, L., Yan, X., \& Zhang, Z. (2019). Research on the Causes of the "Tik Tok" App Becoming Popular and the Existing Problems. Journal of Advanced Management Science, 7(2), 5963. https://doi.org/10.18178/joams.7.2.59-63

YUXIN, Y. (2020). Understanding Y oung Adults , TikTok Usage ----- Real People, Creative Videos that Makes Your Day (UC San Diego; Vol. 1). Retrieved from https:// communication.ucsd.edu/_files/undergrad/ yang-yuxin-understanding-young-adultstiktok-usage.pdf

Zhao, Y., Peng, J., Yang, J., Zhang, E., Huang, L., Yang, H., ... Niu, Y. (2019). Enhancing Prostate $\square$ Cancer $\square$ Specific MRI by Genetic Amplified Nanoparticle Tumor Homing. Advanced Materials, 31(30), 1900928. https://doi.org/10.1002/adma.201900928

Zhou, Q. (2019). Understanding User Behaviors of Creative Practice on Short Video Sharing Platforms - A Case Study of TikTok and Bilibili (Vol. 3). Retrieved from http:// rave.ohiolink.edu/etdc/view? acc_num=ucin 155421202112545 